\title{
Main aspects of sunflower production in Brazil
}

\author{
Cesar Castro and Regina Maria Villas Bôas Campos Leite* \\ Embrapa Soja, Rodovia Carlos João Strass, Acesso Orlando Amaral, CEP 86001-970, Londrina, PR, Brazil
}

Received 16 October 2017 - Accepted 4 December 2017

\begin{abstract}
Sunflower is one of the most important oilseed crops in the world, since its grains have high oil content (38\% to $50 \%$ ), primarily used for the production of high quality oil. The production of sunflower increases the supply of protein meal for animal feeding, which enables the increase of protein production, more specifically meat, eggs and milk. Grain production systems in Brazil have peculiarities, since two to three different crops are grown in a special arrangement, in the same area and year. Notwithstanding the small cultivated area in Brazil of 62.3 thousand hectares, sunflower is used in succession or rotation with other grain crops such as soybean or maize, showing an enormous potential for expansion and can be cultivated from latitudes $33^{\circ} \mathrm{S}$ to $5^{\circ} \mathrm{N}$, especially in the Brazilian Cerrado biome. Sunflower cultivation in succession to soybean as a second summer crop can also reduce environmental impacts because of the more efficient usage of production factors, such as land and sharing of agricultural inputs, machinery, infrastructure and workforce. The success of establishing the sunflower is associated with the adequate management of soil fertility, use of cultivars adapted to different environments, plant arrangement, seed quality and adequate phytosanitary management, among other factors. It also needs strategic actions, planning and, long-term research and technology diffusion.
\end{abstract}

Keywords: Helianthus annuus / oilseed / grain crop

\begin{abstract}
Résumé - Principales caractéristiques de la culture de tournesol au Brésil. Le tournesol est l'une des cultures oléagineuses les plus importantes au monde, car ses graines présentent une teneur en huile élevée (38\% à 50\%) principalement utilisée pour la production d'huile de haute qualité. La production de tournesol fournit également des farines riches en protéines pour l'alimentation animale, ce qui permet d'augmenter la production de protéines, et notamment celle de viande, d'œufs et de lait. Les systèmes de production au Brésil présentent des particularités, puisque seules deux à trois cultures différentes sont cultivées dans une même région et pour une même année. Malgré une petite superficie cultivée de 62300 hectares, le tournesol au Brésil est utilisé en succession ou en rotation avec le soja ou le maïs, et présente un fort potentiel d'expansion car sa culture est possible pour des latitudes allant de $33^{\circ} \mathrm{S}$ à $5^{\circ} \mathrm{N}$, en particulier dans le Cerrado. La culture du tournesol en alternance avec le soja comme seconde culture d'été permet également de réduire les impacts environnementaux en raison de l'utilisation plus efficace des facteurs de production comme la terre et le partage des intrants agricoles, des machines, des infrastructures et de la main-d'œuvre. Le succès de l'implantation du tournesol est associé à une gestion adéquate de la fertilité du sol, à l'utilisation de cultivars adaptés à différents environnements, à une bonne structure de peuplement, à la qualité des semences et à une gestion phytosanitaire adaptée, entre autres facteurs. La culture a également besoin d'actions stratégiques, d'une recherche planifiée sur le long terme, et de diffusion de la technologie.
\end{abstract}

Mots clés : Helianthus annuus / tournesol / Brésil

\section{Introduction}

Sunflower (Helianthus annuus L.) is grown throughout the world, in all the continents. It is an annual dicotyledon species of Asteraceae, the largest family of Angiosperms (Joly, 1993),

\footnotetext{
*Correspondence: regina. leite@embrapa.br
}

originating from North America (Lentz et al., 2001). This crop is among the most important oilseed crops in the world, along with oil palm (Elaeis guineensis Jacq.), soybean [Glycine $\max (\mathrm{L}$.) Merr.], and rapeseed (Brassica napus L.), playing an important role in the world economy (USDA, 2017).

Sunflower seeds have high content (38\% to $50 \%$ ) of high quality oil, primarily used for human consumption. The cake that results after the extraction of oil is used in feedlot cattle, 


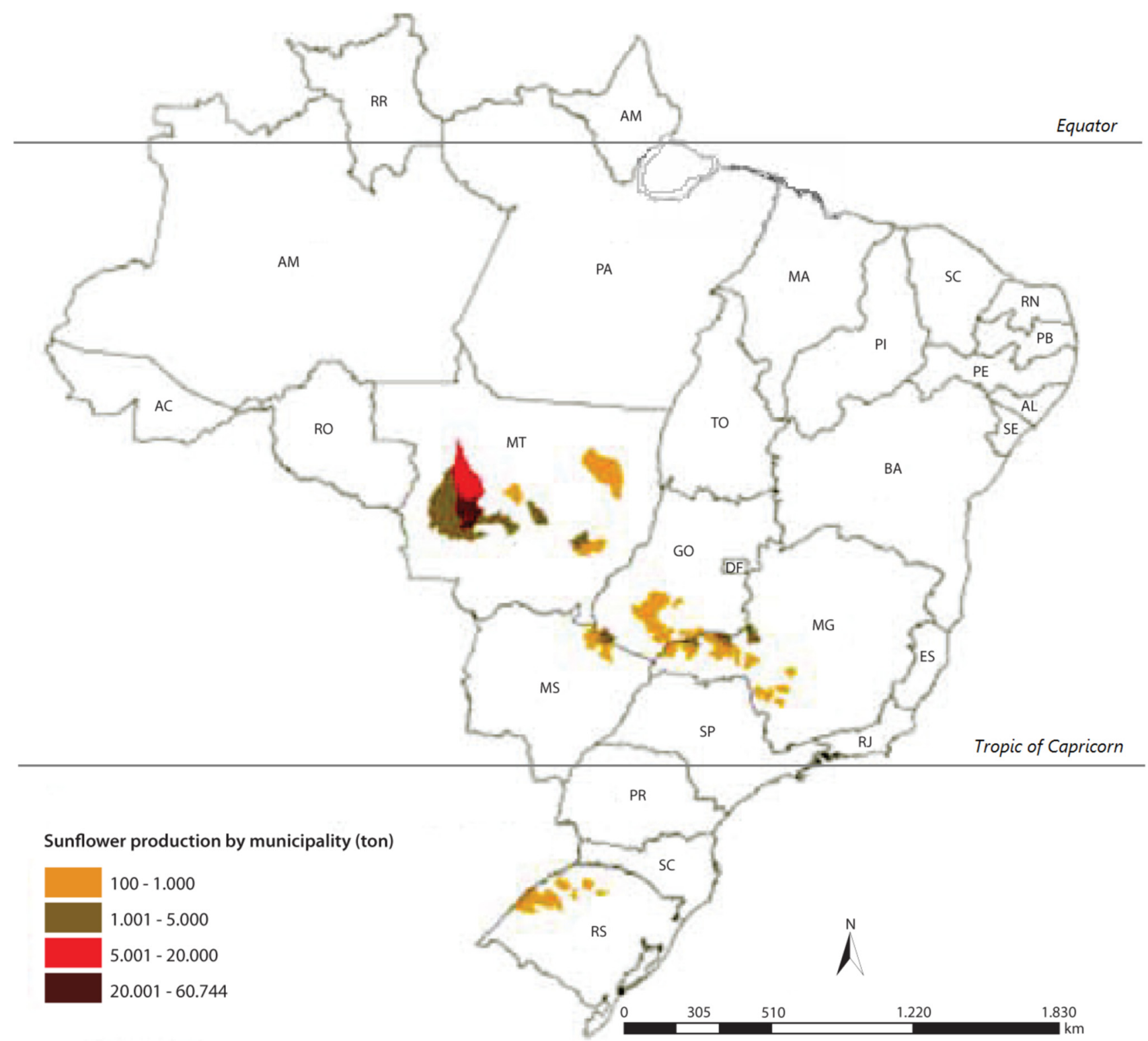

Fig. 1. Sunflower production regions in Brazil, 2017. Source: CONAB (2017).

swine, and poultry diets. Additionally, sunflower oil can be used in a wide range of products in pharmaceutical, chemical and cosmetic industries, in floriculture, honey production and also for biodiesel production. Moreover, sunflower is among the ingredients used in silages and in grain mixtures to feed birds.

This crop has important agronomic traits such as high tolerance to drought, especially in well-structured soils, and to cold and heat compared to most species cropped in Brazil. Furthermore, it can be cultivated from latitudes $33^{\circ} \mathrm{S}$ in the state of Rio Grande do Sul to $5^{\circ} \mathrm{N}$ in the state of Roraima (Leite et al., 2007a). Due to its adaptation to a large production area, with different climate features in light intensity, temperature and altitude, the crop cycle may vary from 80 to 130 days, depending on the cultivar and sowing date.

Because of its adaptive traits, much interest has been devoted to sunflower, mainly as an option for crop rotation or crop succession in grain producing areas, especially in the
Brazilian Cerrado biome. This biome encompasses an area predominantly located in Midwestern Brazil, south of the Equator, between the southern and eastern parts of the Amazon biome and the Tropic of Capricorn. This region is responsible for most of the sunflower production in Brazil (Fig. 1), as well as soybean and maize (Zea mays subsp. mays L.).

\section{Historical landmarks of sunflower production in Brazil}

Sunflower was introduced in the south of Brazil by the end of the 19th century by European settlers and soon adapted to different climatic and soil conditions (Pelegrini, 1985). In 1902, São Paulo State Department of Agriculture distributed seeds to farmers (Ungaro, 1982). In the 1920s, an article in the magazine "Chácaras e Quintais" presented sunflower as the "king among the various species of forage plants", especially 
C. Castro and R.M.V.B.C. Leite: OCL 2018, 25(1), D104

Table 1. Sunflower cultivation areas in Brazil per producing state from the $2007 / 08$ to the $2016 / 17$ growing seasons.

\begin{tabular}{lllllllllll}
\hline State & $2007 / 08$ & $2008 / 09$ & $2009 / 10$ & $2010 / 11$ & $\begin{array}{c}2011 / 12 \\
\text { (thousand hectares) }\end{array}$ & $\begin{array}{c}2012 / 13 \\
\text { 2013/14 }\end{array}$ & $2014 / 15$ & $2015 / 16$ & $2016 / 17$ \\
\hline MT & 60.4 & 41.3 & 40.6 & 39.9 & 47.1 & 50.7 & 126.2 & 86.4 & 25.6 & 31.8 \\
GO & 21.7 & 5.8 & 11.4 & 6.3 & 13.9 & 2.2 & 4.2 & 7.4 & 14 & 16.6 \\
MG & - & - & - & - & 4.3 & 11.0 & 11.3 & 14.0 & 7.0 & 9.3 \\
RS & 18.4 & 23.6 & 13.1 & 7.9 & 3.3 & 2.7 & 3.3 & 1.2 & 3.3 \\
Others & 10.8 & 6.6 & 5.9 & 6.9 & 5.9 & 2.1 & 0.7 & 0.4 & 1.6 \\
Brazil & 111.3 & 77.3 & 71 & 61 & 74.5 & 68.7 & 145.7 & 109.4 & 51.5 & 62.3 \\
\hline
\end{tabular}

Source: CONAB (2017).

indicated for dairy cattle (Ungaro, 1982). The first reference to the commercial production of sunflower in the country was in 1924 (Pelegrini, 1985; Putt, 1997). In the 1930s, sunflower was considered a multipurpose plant, that could be used for production of forage, silage, honey, edible oil and seeds for feeding birds (Ungaro, 1982). Some unsuccessful cultivation attempts were held in Rio Grande do Sul in the 1940s (Dall'Agnol et al., 1994).

In the $1964 / 65$ growing season, sunflower grain production reached more than 4000 tons in approximately 3000 ha, with problems of lack of production technology and market. Cultivars and crop management were the same as those used in Argentina. Despite the good adaptation, these cultivars were very susceptible to diseases (Lasca, 1993; Dall'Agnol et al., 1994). In the second half of the 1960s, new interest arose in the production of sunflower in the state of São Paulo. However, the initiative was not very successful because sunflower yields were lower than those obtained for traditional crops and prices were unattractive (Lasca, 1993). The crop failed to compete with maize, peanut (Arachis hypogaea L.) and cotton (Gossypium hirsutum L.) (Pelegrini, 1985; Dall'Agnol et al., 1994).

Another attempt was made to cultivate this crop in the state of São Paulo in the mid-1970s, without success. The reference price, $80 \%$ of the price of soybean, paid little compensation to the producer (Lasca, 1993). In the late 1970s, sunflower cultivation in Brazil regained interest as a result of the Program of Energy Mobilization of the Federal Government, which stimulated the use of vegetable oils to replace petroleum-based products (biofuel). This resulted in an increasing number of research studies involving castor bean (Ricinus communis L.), peanut and sunflower (Pelegrini, 1985; Dall'Agnol et al., 1994). Nonetheless, in addition to the lack of technology and suitable cultivars, market problems continued to discourage producers. Another attempt to make sunflower an important crop in Brazil was made in the states of Goiás, São Paulo, and in the north of Paraná. The failure was attributed mainly to market problems (Dall'Agnol et al., 2005).

In 1998, the crop got a new chance in Southern Brazil, and an innovative proposal made producers, cooperatives and the oil industries work together. This new option seems to have been effective in the state of Rio Grande do Sul. In the Cerrado region, also from 1998 on, the area planted with sunflower has become expressive, mainly in the states of Goiás and Mato Grosso do Sul, with the support of research results by the Brazilian Agricultural Research Corporation (Embrapa) (Dall'Agnol et al., 2005).
Due to technical and commercial support of an oil milling plant in the state of Goiás (Caramuru Óleos Vegetais, Itumbiara) and research conducted with this species, sunflower became an important economic crop in some production systems of the region in the 2000s (Dall'Agnol et al., 2005). The area planted with sunflower also expanded to the state of Mato Grosso, more specifically in the micro-region of Parecis, stimulated by industries and organized producers (Castro et al., 2010)

As a consequence of sunflower expansion to Mato Grosso, Parecis Alimentos was inaugurated in the 2010s as the first big Brazilian oil milling plant built specifically for processing sunflower. In the beginning of sunflower industrial processing, oil extraction was performed using a mechanical screw press. Despite the high quality of the oil, the meal still contained a lot of oil because of the low efficiency of this type of extraction. However, with the development of seed production, the industrial processing has been changing, and solvent extraction has been adopted. The plants have higher capacity and extraction efficiency as well as higher sunflower meal production.

\section{Recent development of sunflower in Brazil}

Sunflower monoculture cropping area of 62.3 thousand hectares in the last growing season in Brazil is incipient (CONAB, 2017), representing just $0.24 \%$ of the world production area, compared to the main producers such as Ukraine, Russia, the European Union and Argentina, among others, countries that sum up 25.7 million hectares (USDA, 2017). In Brazil, the largest area was grown in $2013 / 14$ growing season ( 145.7 thousandhectares), driven by the interest of the newly built oil industry in the state of Mato Grosso (Table 1). Notwithstanding the small-cultivated area in the country, sunflower is grown in succession to soybean, which covers over 9.3 million hectares just in Mato Grosso or 33.8 million hectares in Brazil (CONAB, 2017), showing an enormous potential for expansion. The potential for area expansion is driven by demand for high quality oils for human consumption, food industry, and the Brazilian government demand for biofuel.

In Brazil, sunflower production is concentrated mainly in the Midwest and Southeast regions, where $80 \%$ and $15 \%$ of the cultivated areas are located respectively (Fig. 1, Table 1). Considering sunflower production per state, Mato Grosso, Goiás and Minas Gerais accounted for 54\%, 23\% and 14\% of 
C. Castro and R.M.V.B.C. Leite: OCL 2018, 25(1), D104

Table 2. Sunflower seed production in Brazil per producing state from the $2007 / 08$ to the $2016 / 17$ growing seasons.

\begin{tabular}{|c|c|c|c|c|c|c|c|c|c|c|}
\hline State & \multicolumn{10}{|c|}{ (thousand metric tons) } \\
\hline MT & 81.4 & 67.5 & 41.7 & 49.0 & 79.4 & 84.7 & 203.3 & 116.5 & 35.6 & 50.1 \\
\hline MG & - & - & - & - & 6.0 & 13.1 & 15.6 & 21.2 & 6.7 & 13.0 \\
\hline $\mathrm{RS}$ & 28.5 & 30.6 & 15.7 & 10.7 & 5.1 & 4.0 & 5.1 & 1.9 & 4.4 & 5.4 \\
\hline Others & 10.2 & 5.9 & 7.3 & 8.1 & 7.1 & 2.6 & 1.1 & 0.6 & 2.4 & 2.6 \\
\hline
\end{tabular}

Source: CONAB (2017).

Table 3. Sunflower yield in Brazil per producing state from the 2007/08 to the 2016/17 growing seasons.

\begin{tabular}{lllllllllll}
\hline State & $2007 / 08$ & $2008 / 09$ & $2009 / 10$ & $2010 / 11$ & $2011 / 12$ & $\begin{array}{c}2012 / 13 \\
(\mathrm{~kg} / \mathrm{ha})\end{array}$ & $2013 / 14$ & $2014 / 15$ & $2015 / 16$ & $2016 / 17$ \\
\hline MT & 1348 & 1635 & 1028 & 1228 & 1686 & 1671 & 1611 & 1348 & 1390 \\
GO & 1242 & 1450 & 1395 & 1411 & 1355 & 1660 & 1815 & 1386 & 1000 & 1302 \\
MG & - & - & - & - & 1395 & 1192 & 1378 & 1517 & 952 & 1400 \\
RS & 1551 & 1296 & 1202 & 1359 & 1549 & 1475 & 1535 & 1617 & 1339 \\
Others & 944 & 894 & 1237 & 1174 & 1203 & 1238 & 1571 & 1500 & 1500 & 2000 \\
Brazil & 1323 & 1455 & 1137 & 1255 & 1563 & 1573 & 1597 & 1376 & 1224 & 1486 \\
\hline
\end{tabular}

Source: CONAB (2017).

the national production of 92.7 thousand metric tons in 2016/ 17 growing season respectively (Table 2 ). The country's main producing area is the micro-region of Parecis, in the state of Mato Grosso, located in the Cerrado biome. Since the climatic conditions in Brazil, mainly rainfall distribution and temperature, allow the cultivation of more than one crop in the same area, in Cerrado, sunflower is cultivated in succession to soybean, immediately after soybean is harvested, allowing the production of a second crop in the same growing season. The same management is adopted for other crops, such as maize, for example, once approximately $69 \%$ of Brazilian maize production (12.1 million hectares) is cultivated as a summer second crop.

Regarding sunflower yield, a measure of production efficiency, the Brazilian average of $1486 \mathrm{~kg} / \mathrm{ha}$ for Brazil (Table 3 ) is low and should be improved compared to the world average of $1778 \mathrm{~kg} / \mathrm{ha}$ (USDA, 2017). In experimental areas or highly technified farms, average yield is about $2500 \mathrm{~kg} / \mathrm{ha}$, reaching up to $5000 \mathrm{~kg} / \mathrm{ha}$ in irrigated areas (Carvalho et al., 2015, 2016). The main reason for the low yield in Brazilian fields is the low level of technology employed for sunflower production, given that it is generally treated as a secondary crop. Furthermore, the country is deficient in technology transfer to farmers.

Compared to soybean, the yield of sunflower in Brazil is lower, but its potential to produce oil is higher due to the high oil content in the seeds $(38 \%$ to $50 \%)$ and high production potential in Brazil (Carvalho et al., 2015, 2016). The adoption of new technological processes, new technical assistance programs, implementation of agro-climatic areas and areas of phytosanitary risk analysis brings benefits to the adjustment of the plant-environment system and, consequently, a greater chance of success and profitability for the agricultural enterprise. Therefore, it is possible to increase both sunflower yield and producers' certainty due to a reduced chance of grain crop failure.

\section{Characterization of the sunflower production system in Brazil}

In Brazil, sunflower is predominantly sown after a springsummer crop, mainly after soybean harvesting. In this production system, producers use most of the production factors available (workforce, machinery, equipment and land), which otherwise would lie idle. Besides reducing the idle period, sunflower crop enhances the diversification of the production system, bringing some important benefits to the property such as: increased revenue and cash flow; better use of the production factors and better ecological balance of the production system.

Taking into account the characteristics of the grain production systems in Brazil, where two to three different crops are grown in a special arrangement, in the same area and year, sunflower planting dates vary considerably depending on the region, going from the extreme South, in the state of Rio Grande do Sul, to the Northern Hemisphere, in the state of Roraima (Leite et al., 2007a). Nonetheless, the planting dates are basically determined by water availability to fulfill the crop water needs, mainly in crop succession systems in the Midwest region of Brazil, and by soil temperature, especially in the South region of the country.

In Brazil, sunflower can be planted as the first crop, planted in the beginning of the rainy season (winter-spring), due to its tolerance to low temperatures in the early stages of growth, or 


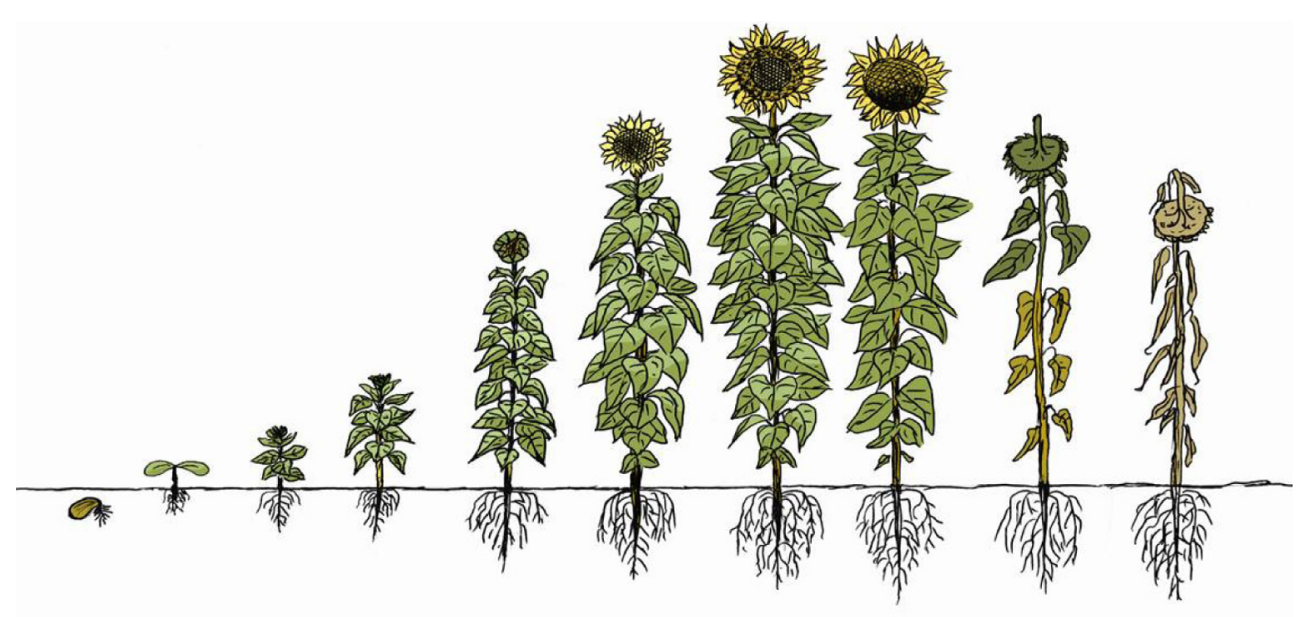

\begin{tabular}{|c|c|c|c|c|c|}
\hline \multicolumn{2}{|c|}{ Vegetative stages } & \multicolumn{4}{|c|}{ Reproductive stages } \\
\hline \multirow{2}{*}{ Emergence } & \multicolumn{2}{|c|}{ Growing stage } & \multirow{2}{*}{ Flowering } & \multirow{2}{*}{$\begin{array}{c}\text { Achene } \\
\text { development }\end{array}$} & \multirow{2}{*}{$\begin{array}{l}\text { Physiologic } \\
\text { al maturity }\end{array}$} \\
\hline & Slow & Accelerated & & & \\
\hline 4 to 10 days & \multicolumn{2}{|c|}{50 to 70 days } & 10 to 15 days & 20 to 30 days & 15 to 25 days \\
\hline Temp. $23^{\circ} \mathrm{C}$ & \multicolumn{2}{|c|}{ Temp. $23-28^{\circ} \mathrm{C}$} & Temp. $<35^{\circ} \mathrm{C}$ & Temp. $20-24^{\circ} \mathrm{C}$ & Dry weather \\
\hline 0.5 to 0.7 & \multirow{2}{*}{\multicolumn{2}{|c|}{0.7 to $6.0 \mathrm{~mm} / \mathrm{day}$}} & 6.0 to 8.0 & 4.0 to 6.0 & \\
\hline $\mathrm{mm} /$ day & & & $\mathrm{mm} /$ day & $\mathrm{mm} /$ day & \\
\hline
\end{tabular}

Fig. 2. Main stages of sunflower development, with the respective duration, temperature requirements, and water needs. Source: Castro and Farias (2005).

can be planted as the second crop (summer-fall), because of its mechanisms of water deficit tolerance. In the states of Rio Grande do Sul and Paraná, South region of Brazil, sunflower is planted at the beginning of the rainy season, from July to October. Thus, a second crop, preferably soybean or maize, can be planted in summer, immediately after sunflower.

In the Cerrado region, the major sunflower country's producing area, the crop is sown after the harvest of the summer soybean, preferably in February or early March. At this time of the year, the crop benefits from the late fall rains (April/May) during flowering and achene development, and harvest can be done during a dry period.

This is possible because sunflower is well adapted to Brazil due to some agronomic and physiological traits that allow the plants to adjust to different edaphoclimatic conditions. Sunflower water use varies according to weather conditions, duration of plant cycle, as well as soil and crop management. Nevertheless, sunflower water needs gradually increase with the development of the plant, from 0.5 to $0.7 \mathrm{~mm} /$ day from planting to emergence to a maximum of 6 to $8 \mathrm{~mm} /$ day at flowering, and decrease after this period up to physiological maturity (Fig. 2). Therefore, water deficit during flowering and grain filling strongly affects the production of sunflower achene and the oil content, a situation that producers try to avoid in the second growing season (Castro and Farias, 2005; Castro et al., 2006).

\section{Segmentation of sunflower production systems}

In Brazil, sunflower production systems can be segmented into two main farmer groups: large-scale enterprises, established mainly in the Midwest region, and small family farms, predominantly in the South region (Castro et al., 2010).

In large-scale enterprises, the producers usually own a dwelling in the property and another in the city; they are medium to large landowners; the farm area is almost entirely used for grain production, reaching 2000 hectares or more; the workforce predominantly earns wages or a salary; they employ industrial technology level, using modern machinery and agricultural inputs; the farms tend to be specialized in just a few producing activities. The main crop in the spring-summer growing season is followed by a second crop (summer-fall) planted after harvesting the main one, usually maize, sunflower, or sorghum [Sorghum bicolor (L.) Moench], aiming to increase profit, taking advantage of the last rains of the season and the residual fertilization of the main crop to optimize the production factors; sunflower areas can reach up to 300 hectares in the farm (Castro et al., 2010).

While in the Midwest region sunflower has been grown in large enterprises, due to the current land structure, sunflower areas are smaller in the South of Brazil. In these small family farms, farmers generally grow soybean and maize as summer crops, and wheat (Triticum aestivum L.), black oat (Avena 
strigosa Schreb), ryegrass (Lolium multiflorum Lam.), rapeseed and sunflower as autumn-winter crops. Farms have around 15 to 50 hectares, but sunflower is, in general, cultivated in 3 to 15 hectares of the farm (Castro et al., 2010).

Regardless the process of sunflower production is held on large-scale enterprises or small family farms, it is common to use machinery and equipment as well as agricultural inputs such as hybrid seeds, fertilizers and pesticides.

Considering that sunflower is part of the grain production system already established in the property, its production process involves all the inputs and outputs from planning to post-harvest, mainly in large properties.

\section{Life-cycle assessment and environmental impacts of sunflower crop}

Although soybean has a much higher economic value, its succession with sunflower reduces the environmental impacts from both crops by sharing resources. Matsuura et al., (2017) performed a life-cycle assessment (LCA) of the soybeansunflower succession cropping system, identified its hotspots, and compared its environmental performance with two hypothetical monocultures, in order to assess its benefits.

Soybean-sunflower cropping system has better environmental performance when compared to the combination of monocultures because of a number of synergies made possible by sharing land use and other resources. The environmental benefits of cropping systems compared to monocultures and the advantages of association of nitrogen-fixing legumes such as soybean with other plant species in a production system have been confirmed (Matsuura et al., 2017). However, excess use of fertilizers, above the crops demand, can cause considerable negative environmental impacts, indicating the need for adjustments in the recommendations (Garcia et al., 2015). Since fertilizer is, the most expensive input in the grain production system, the applied quantities should be determined by soil analysis, avoiding waste, contamination of the environment and greater cost-benefit ratio.

Therefore, the environmental performance of the soybeansunflower cropping system can be improved by optimizing the use of chemical fertilizers. Climate change impacts could be reduced by production intensification, preventing the clearing of native vegetation for agricultural purposes.

The environmental impacts of sunflower have been evaluated in Midwestern Brazil. The results attested to the valuable contributions of sunflower as a second crop, and especially the production practices adopted by the reference farmers studied in the Midwest region of Brazil, rendering complementarities and diversification to both the food (oil and protein) and the bioenergy sectors.

Managerial strengths were identified by Ramos et al., (2014) in rural properties influenced by the introduction of sunflower as an alternative to fallow and/or other crops. The strengths are: improved economic returns; smaller dependence on inputs, especially pesticides; no-till production systems are considered one of the most conservation agricultural practices in tropical regions, with enormous impact in soil protection; productive diversification, with soil cover in high climatic risk periods by a drought tolerant crop; diversity of co-products and market destinations, such as oil, meal, animal feed; soil quality improvement with better nutrient cycling, mainly potassium, and soil unpacking; and sunflower production and processing organized by farmers in a cooperative.

Sunflower cultivation in succession to soybean can also reduce environmental impacts because of the more efficient usage of production factors, such as land and sharing of agricultural inputs, machinery, infrastructure and workforce (Matsuura et al., 2017).

\section{Sunflower oil for food purposes}

Sunflower oil is recognized not only for the nutritional quality, due to the fatty acid profile, but also recognized as a natural and healthy oil, so it is consumed all over the world (Force et al., 2015). In Brazil, the great majority of cultivated sunflower is still of traditional genotypes $(55 \%$ to $75 \%$ of linoleic acid). However, high oleic sunflower (more than $75 \%$ of oleic acid) has also been cultivated. This sunflower oil is characterized by a pleasing and light taste, good frying performance, natural stability, does not need to be hydrogenated and has possible health benefits. Sunflower oil containing a high level of oleic acid is preferred in the food industry, due to a higher oxidative stability (Miller et al., 1987), which increases shelf life of processed food. Currently, Embrapa has been developing high oleic sunflower cultivars, using standard breeding techniques.

Given the great dispersion of production areas, the quality of sunflower oil produced in Brazil may vary according to the region, and the fatty acid profile is strongly influenced by environmental factors, mainly temperature, depending on the latitude at which the sunflower is grown. The oleic/linoleic acid ratio is regulated by environmental factors and genotype (Connor and Hall, 1997; Roche et al., 2004). A strong correlation exists between temperature and the degree of fatty acid unsaturation. High temperature during the growth stages of sunflower, mainly at night, has been identified as the major environmental factor reducing oleic/linoleic acid ratio (Silver et al., 1984). Moreover, high temperature during sunflower seed filling affects the fatty acid composition more seriously than the oil content.

The influence of temperature on the fatty acid composition of oils is well known (Robertson et al., 1971; Merrien, 1992). A research comparing traditional and high oleic sunflower genotypes grown in tropical regions was carried out under several environmental conditions in Brazil (Grunvald et al., 2013). The environment had little influence on the amounts of oleic and linoleic fatty acids in high oleic genotypes of sunflower. However, in traditional genotypes, there was a broad variation in the average amounts of these two fatty acids, mainly due to the minimum temperature. Depending on the temperature, especially during the seed maturation, the amount of oleic acid in the oil of these sunflower genotypes can exceed $70 \%$. Higher temperatures led to average increases of up to $35 \%$ for this fatty acid (Grunvald et al., 2013). The effect of temperature in the amount of oleic acid is due to differences in geographical location where sunflower is grown in Brazil, from latitudes $33^{\circ} \mathrm{S}$ to $5^{\circ} \mathrm{N}$.

The interaction between genotype and environment influences the traditional sunflower genotypes, mainly planted in some areas of the Cerrado region, to produce oil with fatty 
acid composition similar to that obtained from mid-oleic or even high-oleic sunflower cultivars, adding value to the production. Oils with high contents of monounsaturated fatty acids and high nutritional value are greatly valued for direct human consumption or in the food industry. Therefore, the expansion of mid-oleic and/or high-oleic sunflower cultivars may lead to the adoption of public policies that allow the use of sunflower oil with better nutritional and industrial properties.

\section{Use of sunflower for biofuel purposes}

The use of vegetable oils for biodiesel production has been proposed as a renewable alternative to fossil fuels. In the 2000s, especially after the launch of the National Program on Biodiesel Production and Use, several plants were selected as potential crops for their oil production. The program envisaged that the production of biodiesel could be served regionally by crops such as: castor bean and cotton in Northeast region, oil palm and babassu palm (Attalea speciosa Mart. ex Spreng) in North region, soybean in Midwest, South and Southeast regions and sunflower and rapeseed in South Brazil, for example. Other crops or potential plants, such as peanut, jatropha (Jatropha curcas L.), turnip (Raphanus sativus L.), souari nut (Caryocar brasiliense Cambess.), macauba [Acrocomia aculeata (Jacq.) Lodd. ex Mart.] and camelina [Camelina sativa(L.) Crantz], among other oil-bearing crops were considered to be studied. This program called for an important expansion of the biodiesel industrial facilities, promotion of oil crops produced in a sustainable way, with special reference to social inclusion of small family farms, and regional development by the way of employment and income generation (Brazil, 2006).

Considering the fact that the economic and environmental benefits of sunflower for biofuel production are quite the same as those for food production, there is a current debate regarding its destiny. Some authors advocate that such a high quality and noble oil, with a high content of monounsaturated fats, presence of vitamin $\mathrm{E}, \boldsymbol{\beta}$-carotene and phospholipids must be used for human consumption rather than for biodiesel production (Ungaro, 2006). Moreover, an increased demand for high-oleic sunflower genotypes for cooking purposes is currently observed in South America (Castro et al., 2010).

Although sunflower oil is greatly appreciated for direct human consumption, the crop has shown advantages as a raw material for biofuel use such as high oil content, also allowing cold extraction (Gazzoni, 2005), even in small industries or small family farms, for local use of fuel. It has low production cost and a positive energy balance (unit of energy produced as biodiesel/unit of energy used for crop production, when compared with other oil crops (Ungaro, 2006), particularly when sunflower is planted as a second crop after soybean.

Unfortunately, possible negative impacts on natural resources conservation, as well as on social factors such as income generation and distribution, food security, among many other issues are still controversial. These concurrent and potentially conflicting objectives may be better understood through the assessment of environmental impacts, which assessed the sustainability and competitiveness of the major oleaginous crops obtained for biodiesel production in the country (including soybean, oil palm, sunflower, rapeseed and castor bean) (Ramos et al., 2014), for example. Agronomic and socio-economic results showed the preponderance of the soybean production chain, which is very well structured and capable of providing large volumes of oil, enough for both food and fuel (Silva et al., 2010) and still have surpluses of over than 60 million tons of grains to be exported (USDA, 2017).

Despite all possibility and studies with oleaginous plants, soybean is and will continue to be the most used crop in Brazilian biodiesel production, accounting for about $75 \%$ of production. About $15 \%$ of biodiesel comes from bovine fat, the remainder being provided by swine and chicken fat, used frying oil and other fatty materials (ANP, 2017). The amount for each source is variable during the year, due to the seasonality of raw materials. All other oil crop options are not well established yet, due to the lack of knowledge about the production systems, as well as the structure of production, storage and processing, availability of seeds adapted to Brazilian conditions, among others. It is only a dream now and for a long future.

Fortunately, the production of vegetable oil for biofuel uses increases the supply of food, especially animal products such as poultry, pork, beef and fish, as well as milk and eggs, for example. This is mainly due to the higher supply of protein meal for animal feeding. In Cerrado, sunflower meal is basically used for bovine feeding, alone or in mixtures with corn or sorghum meals. For Brazil, it is strategic to increase the global supply of oils or fats for different uses. This will allow oils that are nutritionally more suitable for human health to be used for the edible oil market and the food industry, while the other oils are directed to the energy market.

\section{Sunflower production system}

\subsection{Soil and crop management}

Due to the research development and adaptation of sunflower cultivation in Brazil, the soil fertility requirements for sunflower production do not differ from the needs of other crops, such as soybean or maize. Sunflower is usually grown in soils with $\mathrm{pH}$ from 5.0 to $6.0\left(\mathrm{CaCl}_{2}\right)$, and compaction levels should not limit root development to reduce water and nutrient absorption, especially during the second crop.

A great part of the total content of nutrients absorbed and accumulated by the sunflower crop remains in the field after harvest as crop residues (mainly leaves, stalks and heads). After mineralization of crop residues, these nutrients are readily available to the next crop, which is very important in a crop rotation system. Only nitrogen and phosphorus are exported in high amounts, approximately, $56 \%$ and $70 \%$ of the total accumulated content, corresponding to $23 \mathrm{~kg}$ of $\mathrm{N}$ and $12 \mathrm{~kg}$ of $\mathrm{P}_{2} \mathrm{O}_{5}$ perton of seeds. In this cycling process, potassium is important because, in spite of being required in high amounts, it presents low export rates (Castro et al., 2014). This is particularly important, once Brazil imports about $95 \%$ of the potassium consumed in agricultural production systems.

The performance of a sunflower crop with high yield potential is directly related to adequate management of soil fertility, mainly liming, nitrogen, phosphorus, potassium and, among the micronutrients, boron. Soil analysis is a very efficient tool for definition of the most indicated doses of 
fertilizers, because of high cost of fertilizers in Brazil, most of them imported. After all, nutrient balance is one of the most important factors to enhance yield and rationalize production cost.

Nitrogen is the second most required nutrient by sunflower and plays an important role in the synthesis of seed storage compounds, responsible for the balance between the contents of oil and proteins. Besides increasing the cost of production (Castro et al., 1999), fertilization with high doses of nitrogen raises the content of this nutrient in the tissues and reduces the synthesis of oils, favoring the metabolic pathway of protein accumulation in sunflower achenes (Steer et al., 1984) and can increase disease severity.

Phosphorus is fundamental for grain crops in Brazil and plays important metabolic functions in plant metabolism. Despite the low consumption, phosphorus plays key roles in the synthesis of lipids. However, in soil conditions where it is normally cultivated in Brazil, in a crop rotation system, with nutrient management, it is not common for the appearance of visual symptoms of phosphorus deficiency.

Potassium is the most absorbed nutrient by sunflower. The low availability of potassium in Brazilian soils can cause a gradual decrease in plant growth rates, reducing the productivity of all crops involved in the rotation system, even without the appearance of the typical symptoms of the deficiency, a situation called "hidden hunger". In recent growing seasons, this has been the main nutritional deficiency in large agricultural areas in Brazil. This problem is reduced in sunflower, once the root system has the potential to exploit a deep and large volume of soil.

In general, the most limiting micronutrient to sunflower crop in Brazil is boron. Since boron absorption depends on the concentration of this nutrient in the soil solution, several factors, such as high temperature and reduced soil moisture, may account for the higher deficiency of this nutrient in sunflower. The severity of deficiency can range from mild or imperceptible symptoms ("hidden hunger") to total yield loss due to head drop. The symptoms occur mainly in the phases of flowering and achene filling.

Visual symptoms and nutritional problems associated with copper, iron, manganese and zinc are not frequent under cropping conditions, since sunflower is established in soils that have adequate fertility for soybean or maize production. In general, the contents of these micronutrients are in concentrations higher than the levels considered adequate.

Since sunflower is predominantly planted in rotation with the main crops, high yields can be obtained with relatively small amounts of nitrogen, phosphorus or potassium, sufficient for the replenishment of exports, without neglecting the evaluation of boron, especially in sandy soils.

The yields of previous crops are good indicators of soil fertility. In Brazilian soils with very low to medium phosphorus and potassium availability, which presented high soybean yield, sunflower need of fertilization can range from 40 to $80 \mathrm{~kg} / \mathrm{ha}$ of $\mathrm{P}_{2} \mathrm{O}_{5}$ and from 40 to $80 \mathrm{~kg} / \mathrm{ha}$ of $\mathrm{K}_{2} \mathrm{O}$. Nitrogen amounts can be ranged from $40 \mathrm{a} 60 \mathrm{~kg} / \mathrm{ha}$ of $\mathrm{N}$, depending on the previous crop and sunflower hybrid potential (Castro et al., 2014).

Plant arrangement (population and spacing) is influenced by the genetic potential of each cultivar and plant height, soil and climatic conditions of the region and management used in sunflower. Overall, the ideal population is 40000 to 45000 plants per hectare and the row spacing is $70 \mathrm{~cm}$. It should be noted that the determination of this parameters is a function of the type of machinery and equipment used and may range from 50 to $70 \mathrm{~cm}$ between rows. Many farmers use the same harvesters used for soybean or maize, with few adaptations for harvesting sunflower. Platform, row-crop, and corn headers have all been used successfully with sunflower. Corn platforms need to be modified with a stationary cutting knife before use with sunflower. This is more common in small family farms, while special machines for harvesting sunflower are used in large-scale enterprises.

\subsection{Cultivars}

The success of sunflower crop in the Brazilian production system is associated with the correct choice of cultivars adapted to different environments, among other factors. Nowadays, the assessment and selection of sunflower genotypes of several breeding programs are carried out by the Sunflower Genotype Assessment Trial Network, in a public-private collaboration coordinated by Embrapa. Studies conducted in Brazil since the 1990s have revealed sunflower hybrids with high oil content and high yield potential and, consequently, high oil yield per area (Carvalho et al., 2015, 2016).

In Western Europe, the USA and Argentina, sunflower is often considered a not very profitable crop, and in Brazil it is not different. Brazilian farmers expect to sow and harvest sunflower cultivars well adapted to our soil, climate and pests. Therefore, genotypes that maintain good yields under stressing conditions are needed (Vear, 2016), which can be achieved through breeding programs. Sunflower breeding programs have been developed by private and public sectors aiming to increase the availability of more productive varieties adapted to the Brazilian conditions. Desirable characteristics of cultivars include: mid-early maturity group, reaching physiological maturity at 100 days; oil content of 40-44\%; resistance to Alternaria leaf spot disease, tolerance to toxic aluminum and drought; high oleic profile; tolerance to herbicides of imidazolinone group; adaptation to Brazilian edaphoclimatic conditions. This may lead to better quality oil for consumers and easier crop management, favoring sustainable sunflower production and adding value to the final product.

\subsection{Seed technology}

Sunflower seeds should have high germination rate and vigor for fast and uniform germination and seedling emergence under correct moisture, temperature and aeration conditions. These seed traits must be guaranteed by seed companies and a representative sample should be tested in laboratory before sowing.

As a general rule, seeds with higher oil content such as sunflower deteriorate faster, and consequently germination rate decreases, mainly at higher soil temperatures (Silveira et al., 2005). Seed quality is a frequent problem in Brazil, since seed deterioration occurs during long-distance transport from the seed production sites to the grain production areas, and also 
due to inappropriate storage, adverse sowing conditions such as high soil temperature, insect pests and diseases.

\section{Phytosanitary management}

\subsection{Diseases}

The expansion of sunflower can be affected, among other factors, by the presence of diseases caused by viruses, bacteria, fungi and nematodes. Sunflower hosts over 30 phytopathogenic microorganisms, mostly fungi, which may, depending on climatic conditions that favor the occurrence of pathogens and the infective process, lead to a significant reduction on yield and quality of the product (Zimmer and Hoes, 1978; Gulya et al., 1997).

Diseases are the most limiting factor for crop production in most regions (Zimmer and Hoes, 1978). In Brazil, there is no accurate data on yield losses caused by disease, but it is known that can reach up to $100 \%$, depending on climatic conditions. In the state of Paraná, for example, diseases were considered one of the main factors responsible for the decline in the production of sunflower in the early $1980 \mathrm{~s}$, with the reduction of cultivated area from approximately 80000 ha in 1981 to about 5000 ha in 1984 . The yield, which reached $1800 \mathrm{~kg}$ per hectare in 1980 , was reduced to $480 \mathrm{~kg}$ per hectare in 1981 , caused by excessive moisture and low temperatures by the end of the cycle, which favored the occurrence of Sclerotinia wilt and head rot, caused by Sclerotinia sclerotiorum L. de Bary (Yorinori et al., 1985).

Some diseases have significant importance, like Alternaria leaf spot [Alternariaster helianthi(Hansf.) Simmons] and Sclerotinia wilt and headrot, which are the most severe (Embrapa, 1983). Alternaria disease seems to be prevalent in all sowing dates, in different growing regions (Leite et al., 2006). As sunflower is cultivated in succession to soybean, it is important to mention the risk of infection with pathogens common to both crops, such as Sclerotinia. If there is an epidemic in one crop, the other can be affected, leading to an important loss to the farmer. Sclerotinia head rot is one of the major diseases affecting sunflower worldwide, mainly under low temperature and high moisture. These characteristics make the commercial production of sunflower almost impossible during the fall in Southern Brazil (Leite et al., 2000). Furthermore, this pathogen can leave resistance structures (sclerotia) in the soil, which may remain viable for many years and constitutes a source of inoculum for other host crops, like soybean, canola and beans, which may be affected in the next growing seasons. Otherwise, other important diseases in the world, like downy mildew [Plasmopara halstedii (Farl.) Berl. $\&$ de Toni], powdery mildew [Erysiphe cichoracearum (DC) ex Meret], Phomopsis stem canker (Phomopsishelianthi Munt.-Cvet. et al.) and sunflower rust (Pucciniahelianthi Schwein), are likely to affect sunflower in our country, since it is grown under very different climatic conditions that can favor diseases (Leite, 2014).

Therefore, measures of disease management are mostly preventive and should not be used alone. Thus, effective control is based on an integrated program, which includes zoning for climatic risk, use of genetic resistance to diseases and adequate cultural practices. A great deal of work has been done in the search for genetic resistance to diseases, especially for Alternaria leaf spot, Sclerotinia head rot and downy mildew
(Leite et al., 2007b; Leite and Oliveira, 2015). However, so far no commercial hybrids or varieties have a level of resistance to Sclerotinia suitable for cultivation under favorable conditions to disease (Leite, 2014).

\subsection{Pests}

Soil insect pests that attack in the early stages of sunflower are important because they can reduce plant stand. Uniform plant emergence and adequate final stand of the crop are important factors that result in high yield. Any biotic or abiotic agent that interferes with the final population of plants can affect sunflower production and special care should be taken to establish the crop. Pests that live near the surface of the soil, such as: leafcutter ants [Atta spp. (Hymenoptera: Myrmicinae)], black cutworm [Agrotis ipsilon (Hufnagel) (Lepidoptera: Noctuidae)], fall armyworm [Spodoptera frugiperda (Smith) (Lepidoptera: Noctuidae)] and southern armyworm [Spodoptera eridania (Cramer) (Lepidoptera: Noctuidae)] can cut seedlings before or shortly after emergence, causing death or decrease in crop stand and consequently severe effects on yield.

The most important insects that attack the aerial part of the sunflower, at different times, are: cucurbit beetle [Diabrotica speciosa (Germar) (Coleoptera: Chrysomelidae)], bordered patch [Chlosyne lacinia saundersii (Doubleday) (Lepidoptera: Nymphalidae)] and the pentatomids southern green stink bug [Nezara viridula (L.) (Hemiptera: Pentatomidae)], red banded stink bug [Piezodorus guildinii (Westwood) (Hemiptera: Pentatomidae)] and Neotropical brown stink bug [Euschistus heros (F.) (Hemiptera: Pentatomidae)]. Special attention should be given to the attack of cucurbit beetles at the early crop growth stages. The bordered patch is the most important defoliating insect in sunflower vegetative stages (Moscardi et al., 2005).

Severe yield losses can be observed when birds attack the sunflower crop, especially in small areas. Species such as plumbeous pigeon (Patagioenas plumbea Vieillot) and eared dove (Zenaida auriculata Des Murs) are often found around sugarcane (Saccharum officinarum L.) production areas, whereas birds of family Psittacidae are commonly seen in Cerrado areas. Brazilian environmental laws make the control of these bird populations difficult even when they cause problems in urban areas.

One of the major problems to pest and disease control in sunflower is the lack of registered products for chemical control in sunflower. In the grain production systems, pests, which are polyphagous, have a permanent green bridge, migrating from soybeans or other crops to the sunflower plants.

Another important characteristic that reduces the possibility of controlling insect pests and diseases in Brazil is sunflower plant height. The major Brazilian hybrids reach heights of $1.8 \mathrm{~m}$ or more (Carvalho et al., 2015, 2016), which makes the use of ground spraying equipment difficult from early flowering on. Nonetheless, aerial spraying is efficient and adequate for sunflower in areas where this technique is possible.

\section{Final considerations}

Grain production systems in Brazil have unusual peculiarities when compared to the major grain producers in 
the world, since two to three different crops are grown in a special arrangement, in the same area and year.

Since sunflower adapts to different edaphoclimatic conditions, it can be planted from Southern to Northern Brazil in amended, deep and fertile soils used in the production of more traditional grain crops such as soybean and maize, in crop rotation or crop succession, with better development and high yield. This production system allows a more rational and viable use of soils, leading to agronomic, economic, environmental and social sustainability. In addition to the production of high quality oil, the co-product obtained after oil extraction, named sunflower meal, rich in protein and oil, is used as raw material in animal feed industries, increasing food production, more specifically meat, eggs and dairy products.

Sunflower is a crop with several important characteristics that can be herein mentioned: high oil content in the seeds; lower cost of oil extraction, allowing cold extraction; can be used in crop rotation or succession in grain production system areas, not competing with the main crop; better use of soil water and remaining fertilization of the previous crop.

Although the area effectively planted with sunflower is still small in Brazil, taking into consideration the soil and climate conditions prevalent in the main agricultural areas of the country, this crop could expand to all the regions where soybean, maize, and cotton, for instance, are produced. However, even with these good conditions for crop expansion, many producers are still unaware of sunflower yield potential and production technology.

From an agronomic viewpoint, in addition to favorable conditions, adequate climate, and a defined crop production technology, Brazil already has great biodiversity and potential for expansion of oil-bearing crops aiming to supply oil to food and biofuel industries and meal to animal feed. To be successfully established in profitable and sustainable terms, similarly to what happened during soybean expansion and consolidation in Brazil, sunflower needs strategic actions, planning and long-term research, and technology diffusion.

\section{References}

ANP. 2017. Informações de mercado. Available from http://www.anp. gov.br/wwwanp/producao-de-biocombustiveis/biodiesel/informa coes-de-mercado (last consult: 2017/15/09).

Brazil. Ministério da Agricultura, Pecuária e Abastecimento. Secretaria de Produção de Agroenergia. 2006. Plano Nacional de Agroenergia: 2006-2011, 2nd. ed. Brasília, DF: Embrapa Informação Tecnológica, $110 \mathrm{p}$.

Carvalho CGP, Fujii LH, Amabile RF, eds, et al. 2015. Informes da avaliação de genótipos de girassol 2014/2015 e 2015. Documentos 367. Londrina: Embrapa Soja, 108 p.

Carvalho CGP, Caldeira A, Amabile RF, eds, et al. 2016. Informes da avaliação de genótipos de girassol 2015/2016 e 2016. Documentos 381. Londrina: Embrapa Soja, 94 p.

Castro C, Farias JRB. 2005. Ecofisiologia do girassol. In: Leite RMVBC, Brighenti AM, Castro C, eds. Girassol no Brasil. Londrina: Embrapa Soja, pp. 163-218.

Castro C, Oliveira FA. 2005. Nutrição e adubação do girassol. In: Leite RMVBC, Brighenti AM, Castro C, eds. Girassol no Brasil. Londrina: Embrapa Soja, pp. 317-373.
Castro C, Balla A, Castiglioni VBR, Sfredo GJ. 1999. Doses e métodos de aplicação de nitrogênio em girassol. Sci Agric 56: 827-833.

Castro C, Moreira A, Oliveira RF, Dechen AR. 2006. Boro e estresse hídrico na produção do girassol. Ciênc Agrotec 30: 214-220.

Castro C, Castro CN, Sousa TCR, Lazzarotto JJ. 2010. Sistema produtivo de girassol para a produção de biodiesel. In: Castro AMG, Lima SMV, Silva JFV, eds. Complexo agroindustrial de biodiesel no Brasil: competitividade das cadeias produtivas de matéria-primas. Brasília, DF: Embrapa Agroenergia, pp. 375-420.

Castro C, Oliveira FA, Oliveira Junior, Ramos NP. 2014. Nutrition and fertilization of sunflowers in brazilian cerrado. In: Arribas JE, ed. Sunflowers: growth and development, environmental influences and pests/diseases. New York (USA): Nova Science Pubs, pp. $257-279$.

CONAB. 2017. Acompanhamento da safra brasileira: grãos, v. 4, safra 2016/17, n. 11, décimo primeiro levantamento, agosto 2017. Available from http:/www.conab.gov.br/OlalaCMS/uploads/ arquivos/17_08_10_11_27_12_boletim_graos_agosto_2017.pdf (last consult: $2017 / 11 / 08$ ).

Connor DJ, Hall A. 1997. Sunflower physiology. In: Schneiter AA, ed. Sunflower technology and production. Agronomy monograph 35. Madison, WI: ASA, CSSA and SSSA, pp. 113-182.

Dall'Agnol A, Castiglioni VBR, Toledo JFF. 1994. A cultura do girassol no Brasil. In: Puignau J, ed. Mejoramiento genético de girasol. Diálogo 41. Montevideo: IICA, PROCISUR, pp. 37-41.

Dall'Agnol A, Vieira OV, Leite RMVBC. 2005. Origem e histórico do girassol. In: Leite RMVBC, Brighenti AM, Castro C, eds. Girassol no Brasil. Londrina: Embrapa Soja, pp. 1-14.

Embrapa. Centro Nacional de Pesquisa de Soja. 1983. Resultados de pesquisa de girassol 1983. Londrina: Embrapa-CNPSo, 86 p.

Force EM, Dunford NT, Salas JJ, eds. 2015. Sunflower: chemistry, production, processing, and utilization. Urbana: AOCS Press, $728 \mathrm{p}$.

Garcia KRL, Matsuura MISF, Hirakuri MH, Castro C, von Frihauf C. 2015. Use of Life Cycle Assessment to assess environmental impacts of sunflower oil production in Brazil and proposition of alternatives for its minimization. In: International Conference on Life Cycle Management. Bordeaux (France): pp. 184.

Gazzoni DL. 2005. Óleo de girassol como matéria-prima para biocombustíveis. In: Leite RMVBC, Brighenti AM, Castro C, eds. Girassol no Brasil. Londrina: Embrapa Soja, pp. 145-162.

Grunvald AK, Carvalho CGP, Leite RS, et al. 2013. Influence of temperature on the fatty acid composition of the oil from sunflower genotypes grown in tropical regions. $\mathrm{J} \mathrm{Am} \mathrm{Oil} \mathrm{Chem}$ Soc 90: 545-553.

Gulya TJ, Rashid KY, Masirevic SM. 1997. Sunflower diseases. In: Schneiter AA, ed. Sunflower technology and production. Agronomy monograph 35. Madison, WI: ASA, CSSA and SSSA, pp. 263-379.

Joly AB. 1993. Botânica introdução à taxonomia vegetal. 11. ed. São Paulo: Editora Nacional, 777 p.

Lasca DHC. 1993. Produção de girassol em São Paulo. In: Reunião Nacional de Pesquisa de Girassol. Goiânia (Brazil): pp. 9-11.

Leite RMVBC. 2014. Disease management in sunflowers. In: Arribas JE, ed. Sunflowers: growth and development, environmental influences and pests/diseases. New York (USA): Nova Science Pubs, pp. 165-185.

Leite RMVBC, Oliveira MCN. 2015. Grouping sunflower genotypes for yield, oil content, and reaction to Alternaria leaf spot using GGE biplot. Pesq Agropec Bras 50: 649-657. 
Leite RMVBC, Oliveira MF, Vieira OV, Castiglioni VBR. 2000. Incidência da podridão branca causada por Sclerotinia sclerotiorum em girassol semeado após a colheita da safra de verão, no Estado do Paraná. Summa Phytopathol 26: 81-84.

Leite RMVBC, Amorim L, Bergamin Filho A. 2006. Relationships of disease and leaf area variables with yield in the Alternaria helianthi - sunflower pathosystem. Plant Pathology 55: 73-81.

Leite RMVBC, Castro C, Brighenti AM, Oliveira FA, Carvalho CGP, Oliveira ACB. 2007a. Indicações para o cultivo de girassol nos Estados do Rio Grande do Sul, Paraná, Mato Grosso do Sul, Mato Grosso, Goiás e Roraima. Comunicado Técnico 78. Londrina: Embrapa Soja, 4 p.

Leite RMVBC, Henning AA, Rodrigues SR, Oliveira MF. 2007b. Detecção e variabilidade de Plasmopara halstedii no Brasil e avaliação da resistência de genótipos de girassol ao míldio. Summa Phytopathol 33: 335-340.

Lentz D, Pohl MED, Pope KO, Wyatt AR. 2001. Prehistoric sunflower (Helianthus annuus L.) domestication in Mexico. Econ Bot 55: 370-376.

Matsuura MISF, Dias FRT, Picoli JF, Lucas KRG, Castro C, Hirakuri MH. 2017. Life-cycle assessment of the soybean-sunflower production system in the brazilian Cerrado. Int J Life Cycle Assess 22: 492-501.

Merrien A. 1992. Physiologie du tournesol. Paris : CETIOM, 66 p.

Miller JF, Zimmerman DC, Vick BA. 1987. Genetic control of high oleic acid content in sunflower oil. Crop Sci 27: 923-926.

Moscardi F, Sosa-Gómez DR, Corso IC. 2005. Invertebrados associados ao girassol e seu manejo. In: Leite RMVBC, Brighenti AM, Castro C, eds. Girassol no Brasil. Londrina: Embrapa Soja, pp. 471-500.

Pelegrini B. 1985. Girassol: uma planta solar que das Américas conquistou o mundo. São Paulo: Ícone, 117 p.

Putt ED. 1997. Early history of sunflower. In: Schneiter AA, ed. Sunflower technology and production. Agronomy monograph 35. Madison, WI: ASA, CSSA and SSSA, pp. 1-19.

Ramos NP, Pires AMM, Buschinelli CCA, Vieira HB, Castro C, Rodrigues GS. 2014. Environmental issues in the sunflower crop of Midwestern Brazil: diversification and complementarities in the biodiesel chain. In: Arribas JE, ed. Sunflowers: growth and development, environmental influences and pests/diseases. New York (USA): Nova Science Pubs, pp. 281-296.
Robertson JA, Thomas JK, Burdick D. 1971. Chemical composition of the seed of sunflower hybrids and open pollinated varieties. $J$ Food Sci 36: 873-876.

Roche J, Essahat A, Bouniols A, et al. 2004. Diversified composition of sunflower (Helianthus annuus L.) seeds within cultural practices and genotypes (hybrids and populations). Helia 27: 73-98.

Silva JFV, Richetti A, Hirakuri MH, Castro AMG. 2010. Sistema produtivo de soja para a produção de biodiesel. In: Castro AMG, Lima SMV, Silva JFV, eds. Complexo agroindustrial de biodiesel no Brasil: competitividade das cadeias produtivas de matéria- primas. Brasília, DF: Embrapa Agroenergia, pp. 501-542.

Silveira JM, Castro C, Mesquita CM, Portugal FAF. 2005. Semeadura e manejo da cultura de girassol. In: Leite RMVBC, Brighenti AM, Castro C, eds. Girassol no Brasil. Londrina: Embrapa Soja, pp. 375-409.

Silver JG, Rochester CP, Bishop DG, Harris HC. 1984. Unsaturated fatty acid synthesis during the development of isolated sunflower (Helianthus annuus L.) seeds. J Exp Bot 35: 1507-1514.

Steer BT, Hocking PJ, Kortt AA, Roxburgh CM. 1984. Nitrogen nutrition of sunflower (Helianthus annuus L.): yield components, the timing of their establishment and seed characteristics in response to nitrogen supply. Field Crops Res 9: 219-236.

Ungaro MRG. 1982. O girassol no Brasil. O Agronômico 34: 43-62.

Ungaro MRG. 2006. Potencial da cultura do girassol como fonte de matéria-prima para o programa nacional de produção e uso de biodiesel. In: Camara GMS, Heiffig LS, eds. Agronegócio de plantas oleaginosas: matérias-primas para o biodiesel. Piracicaba: ESALQ-USP, pp. 57-80.

USDA. Foreign Agricultural Service. 2017. Oilseeds: world market and trade. November 2017. Washington: USDA, 39 p.

Vear F. 2016. Changes in sunflower breeding over the last fifty years. OCL 23: D202.

Yorinori JT, Henning AA, Ferreira LP, Homechin M. 1985. Diseases of sunflower in Brazil. Proc. 11th Int. Sunflower Conf. Mar del Plata, Argentina, Vol. 2, pp. 459.

Zimmer DE, Hoes JA. 1978. Diseases. In: Carter JF, ed. Sunflower science and technology. Agronomy monograph 19. Madison, WI: ASA, CSSA and SSSA, pp. 225-262.

Cite this article as: Castro C, Leite RMVBC. 2018. Main aspects of sunflower production in Brazil. OCL 25(1): D104. 